\title{
Managing Succession in a Family Owned Small-Medium Enterprise
}

\author{
Honey Nandlal \\ Financial Consultant at Grant Thornton Indonesia \\ honeysamtanii@gmail.com \\ Suresh Kumar \\ Faculty of Business, President University, Bekasi, Indonesia \\ sureshkumar@president.ac.id*
}

\begin{abstract}
Nowadays, family businesses are of a high number in countries and contribute to the development of the economy. This research was conducted due to the importance of family business survival, and it focuses on factors that affect their performance. Recently, family businesses have been identified as one of the concerns in the global entrepreneurial development agenda. This is because of the existing problem which is caused by family business owners avoid planning and treat succession as a problem instead of an opportunity. This impacts the continuity of the family-owned business. This research is made to emphasize the importance of planning and the drawbacks of negative bias in viewing succession as a problem. This study is expected to make family business owners understand the importance of planning and treating succession as an opportunity to achieve continuity. The qualitative research method was chosen as the method of research with firstgeneration family business owners as the key informants. Three key informants are chosen; $\mathrm{Mr}$ Untoro A. Suryadi, Mr IS and Mr AS. In conclusion, the family business should stop strategizing succession and treat succession as a practice.
\end{abstract}

Keywords: Family business, Family business survival, Succession, Planning

\section{Introduction}

Recently, family businesses have been identified as one of the concerns in the global entrepreneurial development agenda (Lucky, Minai, and Isaiah, 2011). Even though the family business is a fundamental topic, less study has been done on the subject (Claessens and Yurtoglu, 2012). Nowadays, family businesses play an important role in both developed and developing countries in Asia (Kiong, 2005). In Indonesia, based on Winoto and Graito (as cited in Tirdasari and Dhewanto, 2012) the Indonesian family businesses are classified into wholesalers and retailers (36\%); manufacture and distribution (24\%); professional service (14\%); have two different industries (13\%); agriculture and fishery (4\%); construction (3\%); finance and real estate also transportation (2\%); and hotels and entertainment with service (1\%). Thus, it can be concluded that ninety-seven per cent $(97 \%)$ of businesses in Indonesia are family-owned. They further stated most businesses in Indonesia are family-owned, and those are in various fields of businesses, including the

*Corresponding Author 
hospitality industry, especially the restaurant industry (Halim and Kumar, 2019). Considering the evidence that the world has a big number of family-owned businesses, it is important to focus on studying the factors that may affect their performance (Koh, Tan, and Erjercito, 2013) and conflicts (Carter and Justis, 2009).

Four major weaknesses are present in Indonesian family businesses, and those are, financial structure, strategic planning, and business risk management and succession planning (Tirdasari and Dhewanto, 2012). Succession planning is the process of transferring the management and the ownership of the company to the next generation of the family member. Managing a succession plan has many benefits. Hence, the firm must have an advisory board to plan the succession process efficiently (Hyman, 2010). Family businesses have a high interest in knowing how to handle succession well (Haag, 2012). This topic must be highly studied because the societal impact of family-owned firms is high as it increases gross world product and employment (Astrachan, 2010). However, successions usually fail because of a lack of planning (Haag, 2012; Filep and Szirmai, 2012 ). Based on Chia and Holt's research, ninety per cent (90\%) of family business CEOs did less planning and preparation on succession (Chia and Holt, 2009). The succession process does have challenges and dilemmas, but those are parts of succession, especially in Indonesia, where seventy-one per cent (71\%) of family businesses in Indonesia have too many family members involved in the business (Koh, Tan, and Erjercito, 2013).

Although succession has a huge impact on the continuity of the business, studies focusing on succession and how it affects family business continuity are very scarce in Indonesia (Lucky, Minai, and Isaiah, 2011). Many researchers like Christensen (1953), Dyer (1986), Handler (1989), Lansberg (1988), Rosenblatt, de Mik, Anderson, and Johnson (1985), Tashakori (1977), Ward (1987) acquiesce that succession planning highly affects the continuity of family businesses. However, in spite of the importance, researches like Christensen (1953), Handler (1989), Hershon (1975), Lansberg (1988), Tashakori (1977), Trow (1961), Ward (1987) found that succession planning is usually not done by family-owned firms (Handler, 2009). Even though planning the succession process can ensure continuity to the business, many family firms discuss succession rarely. Some businesses choose not to plan, and the reasons are complexity and future conflict connected with this emotionally loaded issue (Checkley, 2010). Thus, this study is expected to provide an understanding of these following problems: 1) How are business transitions through generations by not viewing succession as a negative bias? 2) Why is planning insisted upon in theory but not practised by family businesses? 3) Which factors of family business are included to guarantee family business continuity? The rest of the study is organized as follows: a review on literature, research methods, analysis of the case study, discussions and recommendation.

\section{Literature review}

\subsection{Family Business}

Family businesses are often called as a family-owned enterprise, and it is known as the most popular form of business (Liu, 2013). Further, he argues that when a business is founded and owned by a family but operated by non-family managers; when a business is owned by a big multi-national company but operated by a local 
family; when a business is owned by two unrelated individuals jointly, and each of them has a son working in the company, those businesses can be called as familyowned businesses. Based on Lorna, a family business is a business which surely will be passed on to the next generation for management and control (as cited in Lucky, Minai, and Isaiah, 2011). Westhead, Cowling and Howorth define family business as when a family has strong control over the ownership of the business, involved in the management and consider their business as a family business (as cited in Haag, 2012). A family business does not only consist of a family, and a business, ownership plays a very important role in a family business. Therefore it is called as family-owned businesses (Hollerbach, 2012). Based on Ward, a familyowned company is when the majority of the company decisions is on the possession of the family, and the company will be passed from one generation to the other (as cited in Checkley, 2010). Meanwhile, Churchill and Hatten state that a family business is when the business is owned and managed by a family or by a founder or in this case, any children of his/her which in most cases tend to be the eldest son (as cited in Lucky, Minai, and Isaiah, 2011). Nonetheless, a family business emphasizes the role of the family as the owner, manager, successor, or employee of the business (Ayranci, 2010).

\subsection{Family Business Succession}

The transfer of ownership from a predecessor to a successor in a family business is called succession (Checkley, 2010; Handler, 2009). Succession is believed as a process when owners plan to pass the possession of ownership or transfer their business (Checkley, 2010). Although succession plays an important part while running a business, it is one of the topics that are mostly forgotten and usually untouched by the owner (Haag, 2012). As a result, most family business owners are usually not prepared about what they should do with their company after they retire (Haag, 2012).

The process of succession is not a one-time event. Instead, it is a process with a few stages which can take time; it begins before the next generation enters the business (Checkley, 2010). In a family business, the children join the business as an employee position in the beginning but end up as owners during the succession period (Matser, 2012). Some studies show that the performance of the business, selection of the successor, and succession consequences will show succession as a negative event if the succession is done without a process (Checly, 2010; Aryanci, 2010; Filep and Szirmai, 2012). Moreover, the performance of the succession process depends on the health of the business; quality of living; and the dynamics of the family, all of these are necessary elements to continue with the succession process (Handler, 2009). Nevertheless, succession is typically considered as a problem because only thirty per cent of family-owned businesses survive to the second generation and only ten per cent to the third generation (Handler, 2009). It becomes quite a problem when, for instance, the CEO gets married to one of the board members who is the owner of thirty per cent of the shared, with two of her sons working in the company. A situation like this creates complexity in the family business and to the succession process as people take multiple roles (Hnátek, 2012).2.3 Reciprocal nepotism

Discussion on family business is ridiculous without nepotism. After all, a family business without nepotism is a mere business consisting of blood-related employees, which is common in developing nations such as Indonesia, as is an 
entrepreneurial startup utilizing family capital to staff the operation when the firm cannot afford to hire proper employees. Nevertheless, scepticism surrounding family business as a viable business model often revolve around the narrow talent pool from which successors are nominated from, such that a search on Family Business Review resulted in exactly four articles with the word 'nepotism' on the titles, showing that even in the family business field, the word is preferably avoided.

A search of articles with the word 'nepotism' on the titles in Family Business Review results in a total of 4 articles since its first issue in 1988, one of which is a book review, leaving us with three articles mentioning nepotism in the family business. The oldest article was not available during the search, so rely on the latter two for references. This study adopts the notion of reciprocal nepotism, proposed by Jaskiewicz, Uhlenbruck, Balkin, and Reay (2013). While the notion was not empirically tested, the idea was proven in this study, that privileges such as primogeniture do not prevail in succession. Comparing family firm CEO to their nonfamily counterparts, Salvato, Minichilli, and Piccarreta (2012) agreed with the notion of reciprocal nepotism, reporting that CEO of family firms, while they are family members, are appointed for their qualifications. They also take as much time rising up to the rank as nonfamily CEO does.

\subsection{Negative Bias on Focusing Succession as a Problem}

A negative bias exists towards succession because most family-owned companies' CEO treat succession as a problem to be solved (Haag, 2012; Dyck, Mauws, Starke and Mischke, 2002). The process of succession can only be seen as a long term opportunity if the company is planning and ensuring a smooth transition (Checkley, 2010). However, the way a business view and deal with succession can lead to negative thinking and result in avoiding succession planning (Checkley, 2010).

\subsection{Perceived Business Continuity}

Dealing with transitions over generation and planning succession can be very difficult. Therefore, it has been identified as highly affecting the continuity of family-owned firms (Hnátek, 2012). Further, he stated that perceived future continuity could be defined when a family business provides the future generations employment, wealth, involvement in the business and a legacy. United families are usually committed to succession planning, training of the successor, effective transitions and the continuation of the business (Venter, Merwe, and Farrington, 2012). Further, they argue that the survival of a family business is considered as being of high importance and the more unitary the family, the greater the vision to share a sense of responsibility during the continuity of the family business. However, a family business with negative family business managers is highly unlikely to be committed to the continuity of the business (Haag, 2012). The main reason for family business succession is for the business to continuously develop (Liu, 2013). Hence, the family must make a commitment to the business a priority because it supports the development of a shared vision for the future and the plan for continuity in the business (Hnátek, 2012). 


\subsection{Conceptual Framework}

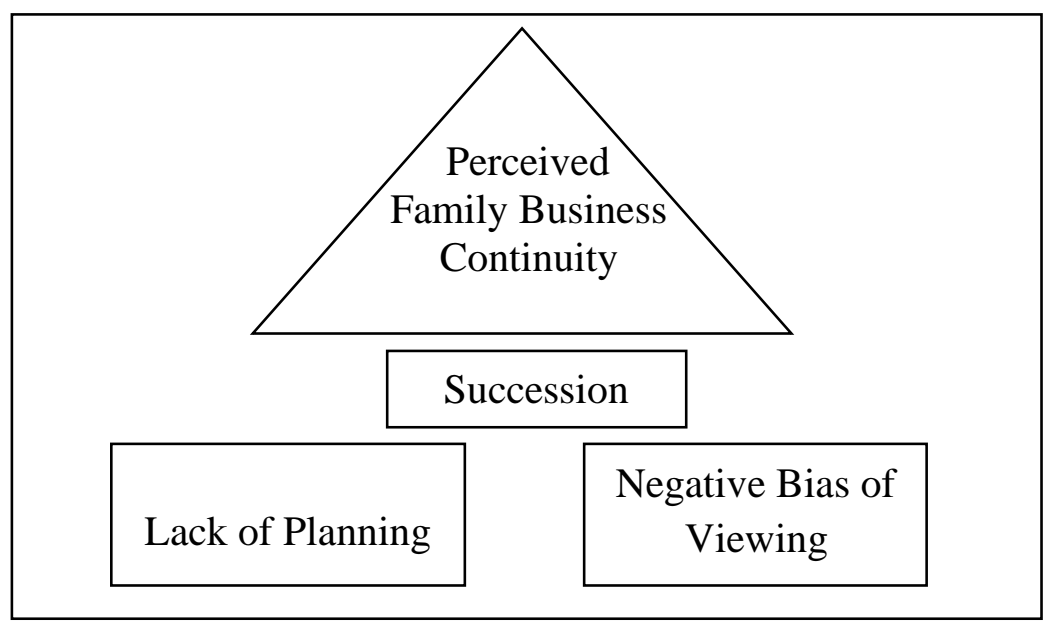

Source: Constructed by the researcher

In this framework, perceived business continuity include two variables which are lack of succession planning which causes failure in succession and negative bias of viewing succession as a problem. These two factors highly influence family business founders or owners to avoid discussing succession. Therefore, the family business fails to continue.

\subsection{Propositions}

The following propositions are developed from the theoretical review and conceptual framework above.

P1: There is a positive relationship between the lack of succession planning and family business continuity.

$\mathrm{P} 2$ : There is a positive relationship between the negative bias of viewing succession as a problem and family business continuity.

\section{Research Method}

\subsection{Research Design}

This study applied the qualitative method focuses on characteristics, definitions, meanings, interactions and experience (Tewksbury, 2009; Creswell, Shope, Clark, and Green, 2006). Key informant interviews can be described as when the researcher conducts in-depth interviews to a group of people who are carefully selected as they can provide needed information, insights, and ideas (Boyce and Neale, 2006). The number of key informants usually ranges from 2-5 (Wagner, Rau, and Lindemann, 2010; Kumar and Prameswari, 2018). Key informant interviews are basically qualitative interviews which are conducted using a guide which lists the topics to be discussed during the session. The interviewer generally takes notes, but if any clarification is needed, the interviewer goes back to the key informant (De Clerck, Willems, Timmerman, and Carling, 2010). The lists of key informants involved were: 


\section{Mr US}

This key informant is one of the owners and the head of the production of a printing company. The company is built under the name of Mangkok Kencana. It is located in Cipinang, Jakarta. This company prints guidelines/ instruction booklets for Suzuki. The informant is one of the owners and is currently responsible for the operational and production part of the business.

\section{Mr IS}

This key informant is the owner of a building wiring company. This company is located in Bekasi. They install and repair wiring systems of lights in homes. This informant is the owner and currently responsible for advising employees on how to get the job done.

\section{Mr AS}

This key informant is the owner of a mineral water company. The company is built under the name of PT. Inovasi Infinita, but they go with their brand name, which is Benzano. This Company is located in Gunung Putri, Bogor. This informant is the owner and advisor and is currently responsible for advising the company and the successor.

The criteria of the data collected are family businesses which have at least gone through two (2) generations as the success of a family business depends on the successful transfer of ownership to the next generation (Duh, Tominc, and Rebernik, 2006). A small-medium family enterprise must have at least two (2) family members and a minimum of five (5) employees and maximum of fifty (50) employees (as suggested in Hnátek, 2013). The samples are stated to be 2-5 people (Wagner, Rau, and Lindemann, 2010). The samples are from both male and female business owners.

To analyze data means to organize and interrogate data in a way which allow researchers to get a glimpse of a pattern, identify a theme, discover relations, development of explanations, interpreting data, develop critiques, or generating theories (Hatch, 2002). As the researcher chooses the inquiry strategy, the researcher must know that it will have a major impact on the procedure of interpretation and analysis (Creswell, 2009). This study applied a cross-case analysis consists of a comparison of the collected cases in order to establish a result; whether there was consistency among the individual case studies based on the theoretical propositions (Yusof and Urbano, 2012; Khan and VanWynsberghe, 2008; Christie, Rowe, Perry, and Chamard, 2000).

In qualitative research, the terms reliability and validity are generally avoided and replaced with the term 'trustworthiness'. Trustworthiness mainly refers to concepts such as credibility, dependability, transferability, and conformability (Tshabangu, 2012). Triangulation is a method commonly used for checking and establishing the Trustworthiness in research. There are five types of triangulation, and those are data triangulation, investigator triangulation, theoretical triangulation, methodological triangulation and environmental triangulation (Guion, 2002; Hussein, 2009). This study applied data triangulation which concerns the use of different references of information to ensure the Trustworthiness of the study (Guion, Diehl, and McDonald, 2011) 


\section{Result and Discussion}

Table 4.1 presents the findings of the study.

Table 4.1: Background Information of Informants

Source: Constructed by Researcher

\begin{tabular}{cccc}
\hline Details & Company 1 & Company 2 & Company 3 \\
\hline Variety of Business & Printing & Building Wiring & Mineral Water \\
\hline Year Business was Founded & 1985 & 2000 & 2007 \\
\hline Current Location & Jakarta & Bekasi & Jakarta \\
\hline Total Employees & 23 & 22 & 19 \\
\hline Family Ownership & $100 \%$ & $100 \%$ & $100 \%$ \\
Generation & First & First & First \\
\hline Succession Planning & Yes & No & Yes \\
\hline Negative Bias & Yes & No & No \\
\hline
\end{tabular}

\subsection{Case Analysis}

\subsubsection{Case 1}

Mr US was born in 1956 in Sidareja and is currently the owner of a printing company. The company prints guidelines/ instruction booklets for Suzuki. The company is under the name of Mangkok Kencana. He started working as an operator in the company and after a few years, his younger brother trust that he could also be one of the owners as well with him and his younger brother. He is currently appointed as the head of the production. In the future, he is planning to take over the marketing position as well. He started off with the operation position then promoted to the head of operations, and he continued in the company as head of productions and owner. It was his own initiative to take on those two positions. He mentions that "in order to have a successful business, the owner must be able to master everything." He learns all the tasks in other divisions by seeing the others doing it, and he says that he does not give up easily, thus, for every problem, he tries to find the possible solution. He gave an example:

"If one of the machines broke, we must find a solution, whether the solution is to call a mechanic or anyone. While the mechanic fixes the machine, look closely at what the mechanic is doing, and by doing that, we are able to fix the machines on our own if the machine breaks again next time."

He continues by saying that it was his decision to take those positions because he is able to complete tasks from other positions as well. He didn't have any considerations to enter another company at that time because he feels that this is a better opportunity. During the entry to the business, his family had no problem and did not show any bad reactions. Since his entry, he never faced any conflicts.

Presently, he chose this position because he feels that as his responsibility towards his business. In order for the business to continue, he must choose this position, as 
the head of the production, because many people before him have tried this position and gave up because they feel that they are not suitable in this field. There have been two (2) to three (3) people in this position before he took over. He has been in the operator position since the year 1986, but it has only been 4 years in the head of production position. He does not feel there are any other alternatives to move to another position. Currently, there is no management team as it is a family-owned enterprise, so they work together to get the tasks done. Mostly they just divide major tasks among the owner, so each owner has their own responsibilities. When talking about meetings, he said that the meetings held in that company are informal. Therefore, they usually make decisions, even if there are no meetings. The decisions are made among the family, which includes him. The company never faces any big problems, but currently, he predicted that, as there is inflation, it will be difficult for the company to renew its machines. If they do not renew their machines, productions cannot increase. Thus the only solution is to renew machines.

He plans to develop the company internally. The company did not do the finishing of products before. Instead, they gave it to another company for the finishing of the products. Therefore he plans to do the finishing of the products as well in the company to increase prices and decrease cost. His plan involves the family, which includes three brothers because it is a family business. As long as the company goes on, succession planning will exist, and as the company is a family business, there is no formal discussion of succession, but there is a plan to transfer ownership to the third brother's son because he receives the most order compared to the other two brothers.

He feels that no matter who the successor is, the quality must remain the same. One thing he wants to change is that he wants the company to develop externally as well after succession. He says that "If we can succeed in printing for one company, why not two." He plans to cover Honda as well after succession, and he targeted next year to cover Honda as well as Suzuki. When asked what problems he feels will appear in the future, he predicted that with the rising inflation, it could be a difficult time for them. He offers the renewal of machines as a solution because, with the renewal of machines, they can decrease the number of employees and increase production.

About succession, he says that there is no formal planning; nonetheless, informally it has been discussed. He has a negative bias of succession since he mentioned that if there is a change in the ownership, the environment will automatically change. However, the decision of who will be the future successor lies in his hands and two of his brothers.

Through analysis of the interview in case 1, the researcher found two (2) elements which are clearly related to the interview. Those elements are lack of succession planning and negative bias of viewing succession as a problem.

1. Lack of succession planning: Discussions of planning usually leads to principles and procedure of formal planning, and this type of planning is based on laws, regulations and norms. Other than that, there is also the existence of informal planning, this type of planning consists of planning activities which are not established as part of an official organization, but it still leads to planned outcomes. It is called informal planning because the process is almost the same as formal planning. The 
main difference is that when defining the goal, formal planning is supposed to follow values and social needs while informal planning aims to achieve similar goals of individuals or a group of people. Procedures are also different in those two types of planning. Informal planning does not have to follow tools and procedures like formal planning (Kušar, 2010). Formal planning is commonly used more by high-performing organizations rather than low-performing organizations and formal plans made by high-performing organizations are highly effective compared to low-performing organizations (Project Management Institute, 2013).

He planned succession informally, and this is concluded from the beginning when he stated that no one had been chosen to the successor. But when asked who is involved in the process, he answered:

"The one who will be more involved in the process is the third brother because he got most orders."

There are no criteria mentioned from the beginning, but from his answer, it can be concluded that the criterion is that the successor will be the son/daughter of the brother that gets most orders. When asked how they make decisions in the company, he answered that decisions are made informally and are usually discussed among the brothers.

2. The negative bias of viewing succession as a problem: The drawback of viewing succession as the problem is that when something is treated problematically, and it is filled with conflict, people are more likely not to do it. Succession may be a challenge, but once it is done, it is extremely beneficial (Haag, 2012). The owner has a negative bias of viewing succession as a problem because he says that as the leader changes, so will the environment. This is known from when he mentioned:

"It is a problem for us, for example, before we were delegates of Pak Yanis and later if the leader changes, so will the environment."

\subsubsection{Case 2}

Mr IS born in 1959 in Tegal and is currently the owner of an electrical engineeringbased company. The company does the installation and reparations of building wires. On the year 1995, he began working with his friend in the electrical engineering field, and he learnt everything there is to know in that field of business. After the year 2000, his friend/ co-worker decided to join another company, and that is when he decided to do freelancing in the same field. He founded capable employees in the same year and has been training them until the year 2010. He is currently the owner and is responsible for controlling the finance in the company and the company itself. He predicted that he would be in the same position in the future.

In the beginning, he started by drilling holes in walls of houses in which the wires will be installed in. He did that because of orders from the owner, as he was still working with his friend. Other than drilling walls, he also learnt how to install the wires and other divisions present in the business. It was his own decision to enter in this field of business because he needed a job at that time. He didn't consider entering into another company at the beginning or even entering into this business 
because he was already settled in selling sacks of rice. He exited that field because the supplier moved into another place, and there are no more suppliers nearby. It was his friend who helped him at that time by suggesting entering that field and helping him to adapt in that business. There are no bad reactions from his family. They were just glad that he got a job. As he began from the position of an employee, he does not notice the reaction that came from other employees. Since he began working in this field, he never faced any conflicts with anyone.

Currently, he says that he did not choose this position, but instead, the position chose him when he felt that the employees are ready and do not need any more supervision, he let them go, and all that is left to do was control the finances, and the business and he feels happy by this because there is more free time for him. He has been the owner since 2010, a total of four (4) years. He feels that there is no other alternative to move to another division because he is already in the highest position.

There is no management team in the company because they are freelancing. Therefore, they never have a meeting with the employees; meetings are attended by family members only. They discuss future development and succession plans. Decisions in the company are not made based on the meetings held but by him as he knows the important details in the company. Challenges faced in this company are usually caused by the employees making a mistake in the installation process, and that causes them to reinstall the system, there are usually some defective products from the supplier, or another problem is when the employees cause a crack in the walls. The solutions to those problems are to fix them without charging the customer.

In the future, he plans to do the freelancing business into a company so that the information reaches the customers easily. In his plan, every employee is involved and also the future successor. His feels the best way to choose a successor is to train the future successor in all divisions after he is capable of handling all divisions in the company, only then the succession can go on and the future successor can take over the business. In that business, he is the only one who drives the succession process. He feels that the willingness of the successor is holding him back because there is no willingness in the part of the successor. He is still confused whether his tasks will change after succession because it depends on the successor, but he is sure that the tasks will not increase. He ensures that the quality and activities will remain the same, even after succession. When discussing the problems that will occur in the future, he says that the same problems and there is no way to avoid those problems.

He has not planned succession, but he did mention that he will plan succession in the future. He is not planning succession currently because he sees no willingness in the part of the successor. He feels that succession is not a problem because it is not difficult when the successor is ready and willing to take over the company. Also, there must be a routine discussion so that the company continues to the next generation. In the future, he plans to expand the company to other countries because currently, the company operates only until Kalimantan.

Through analysis of the interview in case 2, the researcher found two (2) elements which are clearly related to the interview. Those elements are lack of succession planning and negative bias of viewing succession as a problem. 
1. Lack of succession planning: Willingness is an important part of the succession plan for perceived business continuity, without successor willingness the succession plan is of no use (Yang, Xi, and Han, 2013). Based on Venter's research, it shows a direct positive correlation between the preparation level of the successor and perceived business profitability and a successful succession process (Foltz and Marshall, 2012). This company lacks succession planning as they do not see any willingness and preparation or readiness, which is necessary for a successful succession process and perceived business continuity in the part of the successor. This is known when he mentioned:

"No, there is no plan for succession."

And

"When there is no willingness and readiness in the part of the successor, succession cannot go on."

The negative bias of viewing succession as a problem: By not thinking of succession as a negative point, the business will see it as an opportunity which has to be done for continuity. Most businesses see succession as a problem and do not touch the topic of succession while when it is done, they do not face any problems at all. Having no negative bias of succession is related to long term orientation of the business itself (Haag, 2012). In this case, it is good that the owner does not see succession as a problem as he only sees willingness and readiness in the part of the successor as the only two factors that are needed for succession.

\subsubsection{Case 3}

Mr AS was born in 1954 in Cikampek and is currently the owner and advisor of a mineral water company. The company produces bottled and gallons of mineral water. The company is built under the name of PT. Inovasi Infinita. The company operates in Gunung Putri, Bogor.

“We've been seeing an opportunity from the year 2007 until 2008 for selling mineral water since the prices of mineral water have been rising and many people face difficulties in obtaining mineral water, so we begin to find, coincidentally, we found a company where the owner is an elderly who is looking forward to exiting the business, so we planned to take over their business."

At the present time, he acts as the owner and the advisor in the company. In the future, he is looking for less involvement in the business. He started the business with his own initiative. He learned that in order to make any decision in the business, cost and efficiency must be considered. In the beginning, he did not have any other consideration because he really saw this as a big opportunity which can be useful for their future. His younger brother and his younger brother's friends helped him to adapt to the business. When he entered the business, his family was really supportive because mineral water is a daily need. Since the beginning, he never experienced any conflict amongst the co-workers.

He is now in his current position because the system which has been applied so far is quite simple. Thus, he is not involved in the daily operations, and he leans more towards making strategies and plans for the future. In the beginning, towards the second year, he tried to be involved in the day-to-day operations, but until now he 
acts as the advisor and is updated from reports and meetings made/ held by the company.

This company has a management team which is taken from a logistics company and other companies as well for the day-to-day operations. Meetings are held every Monday morning involving the management team discussing problems, performance and targets to be achieved, visions and missions, solutions to difficult problems, which is when the owner comes in and help by giving a few pointers. Decisions are made not only by the owner and top management but also based on the employees and the meetings held. Small challenges are faced by every company, and this company face small challenges as well which are in the payment of the product and product sourcing, packaging prices, and other small problems which are not a big deal for the company.

For the future of the company, he plans to continue increasing the revenue, where we can achieve economies of scale. In his plan, each employee is involved, to continue to decrease cost and receive new clients. While discussing succession, he mentions that the succession process had already been done and ownership currently lies in the hands of his second son. The successor learned everything, right from the bottom until the administrations and up to top management. Mr AS himself is the one who drives the succession process. He does not feel that there are any challenges in the succession problem as his son is ready not long after he took over the company.

After the succession process, his responsible lessen, and he just checks the monthly reports. A few things he feels should remain the same after succession is that the vision and missions which are providing clean mineral water and also good and friendly services. The things he feels should be different after succession is that the increase in ideas and innovation, ways to be efficient or any new technology which can modernize the system. He predicted future challenges to be the competitors in the market and also the increased cost in raw materials. The only solution in the case of competitors is to differentiate their products and segmenting; selling to their corporate relations. While for the rising prices, the solution is to adjust their prices as well.

The day-to-day operation in the company is more organized since succession to the next generation. Before succession, there is no routine of talking about succession since the successor seems quite ready for a job experience after graduating. The thing which makes succession seems less of a problem is when the team adapts well with the new successor, and there is no resistance from the part of the successor. In the future, he plans the next step to be increasing revenue, profit and efficiency.

Through analysis of the interview in case 1, the researcher found two (2) elements which are clearly related to the interview. Those elements are lack of succession planning and negative bias of viewing succession as a problem.

1. Lack of succession planning: There is never a right time to talk about succession, and this is why most family businesses are left with uncertainty. This causes them to have no time to plan succession well and affect the continuity of the business. Succession planning is important, and there must be an existence of a routine to discuss succession (Hall, 2014). Even though currently succession has been done in this company, however, before the succession process; there is no 
routine of talking about succession, and they still face a successful succession process, the second generation will have no idea on how to pass the business to the next generation because he has not heard of a succession plan before. In my opinion, the second generation will do what his father did with him which is waiting for his son or daughter to graduate and give him a job experience, but that does not guarantee that the next generation would continue the business. Family businesses bring the history to the future; what the first generation did, will be repeated by the second generation (Haag, 2012). This is known when he stated that:

"There is no routine of talking about succession because I know that my son will need a job experience after graduating from college, and the first time he joined, he really showed interest."

2. The negative bias of viewing succession as a problem: an optimistic owner is highly influential in the company, hence, if the owner sees succession as a problem, so will the employees in the company (Haag, 2012). Fortunately, there is no negative bias in this company. They treat succession as an opportunity more than a problem. This is known when he stated:

"There are no challenges in the succession process because since the owner took over the company, the successor is ready to join not long after, and he adapted with the team and environment well."

\subsection{Cross Case Analysis}

\section{Lack of succession planning}

Due to the lack of succession formal planning amongst family members in familyowned small-medium enterprises, family businesses survive only until the second generation. The similarities in these three cases are that the three informants are owners of family businesses, and three of them did not do any formal planning for succession. The only owner who did informal planning was the owner who owns the printing company, Mr US. This company is owned by three brothers for 29 years; therefore, they are currently talking about succession. The building wiring and the mineral water company did not plan succession. The building wiring company are planning to do succession when there is willingness and readiness in the part of the successor while the mineral water company already transferred ownership to the second generation thus they are not planning to talk about succession currently.

\section{Negative Bias of Viewing Succession}

Most companies in the world view succession as a problem, thus, they plan succession at the very end, or they do not do it at all. Family businesses in Indonesia contribute to economic growth; thus, their continuity is very important. Treating succession as a problem will not allow family-owned companies to grow (Maharani, 2014). In this case, unfortunately, it shows one out of three companies treat succession as a problem and that company is the one going through the 
succession planning phase currently. The other two companies, in which one has gone through succession without a plan, do not treat succession as a problem

\section{Conclusion and Implications}

\subsection{Conclusion}

The process of succession is an on-going part of a family business. The process of succession comes with problems, but it also includes opportunities, creativity and continuity. Succession includes the transfer of ownership and change of business positions. Most family businesses think of succession as a formal matter and a problem which they would not want to face. Succession originates from socialization; it progresses through planning. A succession is a normal event which takes place to ensure the continuity of a business.

A family business differs from other types of businesses since it involves a family with shared history and future. Multiple generations are usually connected through socialization where values and behaviours are shared. Those shared values and behaviours are extended into the business; thus doing business is a part of socialization. Succession is included in everyday life in a family business. This is why family members must socialize about succession. Therefore, it must be planned in order to clarify the system in each generation. When there is a willingness in the younger generation, the business goes through succession without any formal planning. It is not just about preserving the business, but also to evolve.

Other than those cases of the family businesses I interviewed, I have learned a lot about succession in general, and how succession planning benefits the company. Based on Dyke, a negative bias can be found in family businesses in viewing succession. Viewing succession as an opportunity instead of a problem changes the whole perspective of succession. The lack of optimism inspired me to conduct this research. The main reason for this study is to propose a new way of thinking about succession. From one of the cases discussed, it shows that succession planning originates from socialization and progresses without a strategy. When strategizing succession is treated as a practice, it becomes easier for the company not to see it as a problem. As suggested in Haag's research, when succession is practised in everyday life, the problems and opportunities become a routine to be dealt with every day (Haag, 2012).

\subsection{Recommendation}

\section{Family-Owned Small Medium Enterprises}

1. Practice Perspective: It is essential for a family-family small-medium enterprise to see succession in a practice perspective in order to ensure perceived business continuity. By practising succession, successors can be chosen at an earlier stage, and preparation can be done. Earlier planning and preparation allows the older and younger generation to obtain more knowledge from each other. Embracing succession is beneficial for family-owned small-medium enterprises.

2. Socialization: Socialization is done every day in our lives; thus instead of planning, family businesses could socialize about succession in their day-to-day lives. The word 'planning' involves formulating a strategy; this is why family 
businesses avoid the topic of planning. Socialization allows stepwise strategizing in which a detailed plan is not made directly in a day. Decisions in any company should be flexible and rational. Therefore, socialization about succession amongst family members is advantageous.

\section{Future Research}

Future researchers can use the variable-oriented approach in which they collect more cases and add variables to be discussed. This research focuses on two problems to why succession is not being done in most family-owned small-medium enterprises. Future researchers can focus on more problems which affect succession, for instance, the willingness of successors, preparation of successors, management teams, etc. They could also focus on the benefits of succession, other than the continuity of the business.

\section{References}

ACAPS. (2012, May). Qualitative and Quantitative Research Techniques for Humanitarian Needs Assessment. Retrieved November 12, 2014, from ww.acaps.org: $\quad$ http://www.acaps.org/img/documents/qualitative-andquantitative-research-techniques-for-humanitarian-needs-assesment.pdf

Astrachan, J. H. (2010). Strategy in family business: Towards A Multidimensional Research Agenda. Journal of Family Business Strategy, 6-14.

Ayranci, E. (2010). Family involvement in and institutionalization of family businesses: A research. Business and Economic Horizons, 1.

Baxter, P., and Jack, S. (2008). Qualitative Case Study Methodology: Study Design and Implementation for Novice Researchers. The Qualitative Report Volume 13 Number 4, 4-6(16).

Boyce, C., and Neale, P. (2006). Conducting In-Depth Interviews: A Guide for Designing and Conducting In-Depth Interviews for Evaluation Input. 5$8(15)$.

Canada, B. D. (2014, March). BDC Study. Retrieved from ADVISORY BOARDS: AN UNTAPPED RESOURCE FOR BUSINESS: http://www.bdc.ca/EN/Documents/analysis_research/bdc_study_advisory_ boards.pdf.

Carter, J., and Justis, R. (2009). The Development of Successors from Followers to Leaders in Small Family Firms: An Exploratory Study. Family Business Review, 109-124.

Checkley, T. (2010). Succession in Small and Family Businesses. 12-18(85).

Chia, R., and Holt, R. (2009). Strategy Without Design. The Silent Efficacy of Indirect Action. Cambridge: Cambridge University Press., 189.

Christie, M., Rowe, P., Perry, C., and Chamard, J. (2000). Implementation of Realism in Case Study Researrch Methodology. 26 (36).

Claessens, S., and Yurtoglu, B. (2012). Corporate Governance in Emerging Markets: A Survey. SSRN, 9.

Creswell, J. W., Shope, R., Clark, V. L., and Green, D. O. (2006). How Interpretive Qualitative Research Extends Mixed Research Methods. Research in The Schools Vol. 13 no. 1, 1-11, 1-4 (11).

Creswell, J. (2009). Research Design: Qualitative, Quantitative, and Mixed Methods Approaches 3rd edition. Los Angeles: Sage Publications, Inc. 
De Clerck, H. M.-L., Willems, R., Timmerman, C., and Carling, J. (2010). Instruments and guidelines for qualitative fieldwork. 3-20(29).

Directors, A. I. (2009, October). SME Business Owners/Director. Retrieved from companydirectors.com.au http://www.companydirectors.com. au/ /media/Resources/Director\%20Resource\%20Centre/Directorship\%20i n\%20your\%20organistation/00660_SME_FY_The_Benefits_of_an_Advis ory Board_web.ashx.

Duh, M., Tominc, P., and Rebernik, M. (2006). Succession Issues within Family Enterprises in Transition Economies. 2-5(29).

FFI, F. F., and CAFE, C. A. (2011). The Business of Family Business: Why Family Business is Different. In G. Walsh, Family Business Succession: Managing the All-Important Family Component (pp. 1-12). Canada: KMPG LLP.

Filep, J. C., and Szirmai, P. (2012). Family Businesses - Focusing on Succession. Business and Management Ph.D. Program, 5(25).

Foltz, R. D., and Marshall, M. I. (2012). Family Business Decision-Making: Factors and Influences on Choosing a Successor. 8(46).

Gravelle, M. (2010). Four Steps to Effective Succession Planning. 2-4.

Guion, L. A. (2002). Triangulation: Establishing the Validity of Qualitative Studies. $1-3(3)$.

Guion, L., Diehl, D. C., and McDonald, D. (2011). Triangulation: Establishing the Validity of Qualitative Studies. 1-3(3).

Haag, K. (2012). Rethinking family business: From a problem to solve to an ongoing practice. JIBS Dissertation Series No. 082, 13-40 (237).

Halim, J. and Kumar, S. (2019). Success Factors of Independent Restaurants in Karawang Barat. CV. Rasi Terbit.

Hall, C. (2014, June 5). Forbes. Retrieved 12 17, 2014, from Forbes Website: http://www.forbes.com/sites/ey/2014/05/06/succession-planning-is-yourfamily-business-parachute.

Handler, W. (2009). Succession in Family Business: A Review of the Research. $3(26)$.

Hatch, J. A. (2002). Doing Qualitative Research in Education Settings. Albany: SUNY press.

Hnátek, M. (2012). Succession Planning and Generational Transition: The Greatest Challenges Family-owned Businesses. Journal of Eastern Europe Research in Business and Economics Vol. 2012 , Article ID 421949, 1.

Hnátek, M. (2013). Succession Problems in Family-Owned Businesses: An Example from the Czech Republic. The Business and Management Review, Volume 3 Number 3, 33-34.

Hollerbach, A. (2012). Company Succession in small and medium sized family companies. Následnost společnosti $\mathrm{v}$ malých a středních rodinných společnostech, 20.

Hussein, A. (2009). The use of Triangulation in Social Sciences Research: Can qualitative and quantitative methods be combined? Journal of Comparative Social Work, 5-10(12).

Hyman, V. (2010, February). 10 Things Every Board Member Needs to Know. Retrieved from firstnonprofit: http://www.firstnonprofit.org/wpcontent/uploads/2014/04/Sustaining-Great-Leadership.pdf.

Hyett, N., and Amand Kenny, V. D. (2014). Methodology or method? A Critical Review of Qualitative Case Study Reports. International Journal of Qualitative Studies on Health and Well-being, 1-4(12). 
IFC, I. F. (2011). IFC Family Business Governance Handbook. World Bank Group, 14-16.

Johnson, R. B., and Christensen, L. (2013). Educational Research: Quantitative, Qualitative, and Mixed Approaches, fifth edition. In R. B. Johnson, and L. Christensen, Educational Research: Quantitative, Qualitative, and Mixed Approaches, fifth edition (p. 34(744)). London: SAGE publications.

Khan, S., and VanWynsberghe, R. (2008). Cultivating the Under-Mined: CrossCase Analysis as Knowledge Mobilization. Volumme 9 No.1. Art 34, 1$3(13)$.

Koh, A., Tan, E., and Erjercito, J. (2013, March). Documents: Deloitte. Retrieved from Deloitte:http://www.deloitte.com/assets/DcomVietnam /Local\%20Assets/Documents/Deloitte_SMU_Asian_Business_Families_R esearch_2013.pdf.

Kohlbacher, F. (2006). The Use of Qualitative Content Analysis in Case Study Research.

Kothari, C. R. (2004). Research Methodology: An Introduction. In C. R. Kothari, Research Methodology: Methods and Techniques (pp. 1-5(398)). New Delhi: New Age International (P) Ltd., Publishers.

Kotler, P., Keller, K. L., Brady, M., M., G., and and Hansen, T. (2009). Marketing Management. Pearson Education.

Krisbiyanto, N. (2004). Human Resources Management Succession Planning.

Kumar, K. (1989). Conductting Key Informant Interviews in Developing Countries. A. I. D. Program Design and Evaluation Methodology Report no. 13, 221(40).

Kumar, S., Prameswari, Q. (2018). The Determinants of a Successful Family Business Succession in Indonesia: A Multiple Case Study. International Journal of Family Business Practices, Vol. 1 No. 2.

Kušar, S. (2010). Informal planning practices: some evidence from Slovenia. Journal of Landscape Studies, Vol. 3, No. 2-5(7).

Lamsfuß, C., Wallau, F., Bottcher, B., Düren, J., Jochum, A., and Winkler, A. (2012, may). BDI The Voice of Germany Industry. Retrieved from dbresearch: $\quad$ http://www.dbresearch.com/PROD/DBR INTERNET _DEPROD/PROD0000000000297876/Major+family+businesses+in+Ger many.pdf.

Leach, P. (2011). Family Busines- The Essentials. Profile Books, London.

Liu, Z. (2013). Designing Strategies for Managing Family Business Succession during the Transitional Period: Case of ACCEC. Kemi-Tornio University of Applied Sciences, 16-43.

Lucky, E. O.-I., Minai, M. S., and Isaiah, A. O. (2011). A Conceptual Framework of Family Business Succession: Bane of Family Business Continuity. International Journal of Business and Social Science Vol. 2 No. 18, 3 (8).

Maharani, A. (2014). Analisis Keberlanjutan Bisnis Millik Keluarga (Studi Kasus Empat Bisnin Milik Keluarga Di Jakarta. 2(11).

Martinez, J. (2013, March 12). Special Report: CEIBS Kaifeng Centre for Family Heritage. Retrieved from CEIBS Kaifeng Centre for Family Heritage: http://www.ceibs.edu/cfh/special/110842_2.shtml Matser, I. A. (2012). Strategic Resources and Family Firm Performance. ISBN: 978-90-807379$0-7,14-16$.

McAnany, S. (2012). The Use of Patient Capital as a Funding Mechanism in Health Sector Initiatives. 7. 
Northcote, M. T. (2012). Selecting Criteria to Evaluate Qualitative Research. Education Papers and Journal Articles, 9-13 (13).

Project management Institute, I. (2013). The High Cost Of Low Performance: The Essential Role Of Communications. 6 (10).

Salim, L., Shariff, M. N., and Arshad, D. A. (2018). Predecessors' Attitude Toward Conflict Predictor of Family Business Sustainability. International Journal of Family Business Practices, Vol. 1, Iss. 1, pp. 1-13.

Sembiring, M. (2008). SMEs Growth and Development in Indonesia. Joint Regional Workshop on SME Development and Regional Economic Integration.2-3(11).

Tavallaei, M., and Talib, M. A. (2010). A General Perspective on Role of Theory in Qualitative Research. The Journal of International Social Research Volune 3/11, 1-3 (8).

Tewksbury, R. (2009). Qualitative and Quantitative Methods: Understanding Why Qualitative Methods are Superior for Criminology and Criminal Justice. Journal of Theoretical and Philosophical Crimininology, Vol 1 (1), 1-3 (21).

Tshabangu, J. (2012). Perceptions of Stakeholders onn how Schools in the Fezile Dabi District Manage Reputation. 11-12 (19).

Venter, E., Merwe, S. V., and Farrington, S. (2012). The Impact of Selected Stakeholders on Family Business Coninuity and Family Harmony. Southern African Business Review Volume 16 Number 2, 70.

Wagner, S. M., Rau, C., and Lindemann, E. (2010). Multiple Informant Methodology: A Critical Review and Recommendations. Sociological Methods and Research 38(4) 582-618, 6-7 (37).

Wallace, J. (2010). Family-Owned Businesses: Determinants of Business Success and Profitability. 24-30 (97).

Wyk, R. v. (2012). Constrictive vs. Distinctive Familiness and the Culturing of Familiness Capital (FamCap). African Journal of Business Management Vol. 6 ISSN 1993-8233 academic journals, 9894.

Yang, J., Xi, J., and Han, X. (2013). The Intervention Effects of Succession Planning on Offspring's Willingness to Take over Family Businesses-An Experimental Study Based on Behavioral Decision-Making and Opportunity Cost Theories. American Journal of Industrial and Business Management, 1-4(8).

Yusof, S. N., and Urbano, D. (2012). Success Factors in Entrepreneurship: The Case of Malaysia. 33-35(112).

Zucker, D. M. (2009). How to Do Case Study Research. 2-7(17). 